\title{
Study on Problems and Countermeasures in Good Politics Order Establishment Process
}

\author{
Wang Shiyou, Liu Junlong \\ College of Literature and Law, Sichuan Agricultural University, Ya'an, Sichuan 625014 China
}

\begin{abstract}
In current process of Chinese market economy development and constant deepening, various social contradictions also appear, which is a challenge to market economy, and also a serious test for current politics order. This paper makes an analysis of existing problems in current politics order establishment process from the several aspects of current system, system construction and citizen education, and it tries to propose relevant solutions.
\end{abstract}

Keywords-politics authority; fair justice; capital power; polarization between the rich and the poor;

\section{INTRODUCTION}

China is now currently in the constant key period of constant deepening market economy development, and this period is not only the constant enriching and improving period of Chinese economy society, but also the period of various risks and contradictions. It is not only a serious test for profound development of Chinese economy society, but also a great challenge for Chinese politics order stability. In order to maintain the economic society stability and politics order healthy development, we can positively establish our Chinese governmental authority, in order to have a good development of Chinese economic society, and establishing good political order is a very necessary politics measure.

\section{EXISTING PRoblems OF CURRENT CHINESE GoOD POLITICAL ORDER ESTABLISHMENT PROCESS}

In current Chinese politics order establishment process, social public order consciousness and current system construction obtain a long-term process. But on the other hand, the current politics order establishment still exists some problems that should not be ignored.

First of all, "capital power" and "power capital" trend weaken governmental authority, in order to further threaten existing politics order. The so-called capital power, just as some scholars point out that, it mainly refers to that individuals or profit groups use their money (capital) to obtain political benefit for individuals or agents, in order to obtain the maximum and more profit or protect the individual and benefit mutuality's profit, so as to realize capital preservation and appreciation." And the power capital refers to that national staff use their own power to obtain special benefit for individual and family (relatives) or other relevant profit mutuality, and finally it brings money income.

"Capital power" and "power capital" has the maximum harm, which is that social citizens causing human inequality, namely, a few occupying a lot of public resource to realize benefit, which is to take damaging or sacrificing a lot of people's benefit as the premise. This can make social community's political participation enthusiasm and their trust for government constantly reduces, so as to cause government authority and political control to be weakened.

Thus, governmental authority and political control weakening will necessarily make social political order become weak and unstable.

Second, civil society has not yet formed, resulting in civil political participation to lack of rationality and order.

Citizen society has the several features: first, it is the awaking subject consciousness of citizens, emphasizing its own freedom and equality; secondly, citizens advocate adopting negotiation and communication methods to solve profit dispute. Secondly, broad political participation and rich and mature political skills are the third feature of civil society.

Finally, social inequality and polarization between the rich and the poor cause social unrest. We must admit that currently China exists the fact of social inequality and polarization between the rich and the poor. From 1988 and 2007 , the highest income of the $10 \%$ population and $10 \%$ of the lowest income has income difference, increasing from 7.3 times to 23 times. In gap between urban residents and rural residents within the gap between urban and rural residents, it has achieved the highest level of history. In 2007, urban and rural resident income difference achieves $64.45 \%$ of total income difference of residents "contribution rate". Some people use their own social resource, gathering a lot of social wealth, and more ordinary people should shoulder heavy life burden.

\section{EXISTING PROBLEM REASON IN CHINESE GOOD POLITICAL ORDER CONSTRUCTION}

First, about "capital power" and "power capital" problem. American scholar Robert Dahl said, "suppose an individual of political system, it occupies the relative position to arrange according to its social important political resource, such as wealth, income, knowledge, reputation and spread control, in order to control the police and army. If each person's relative positions are the same, so as to form a complete mutual association, resource inequality is only accumulative. The individuals have more resources, and their other resources are more.

Thus, we can see that "capital power" and "power capital" reason is that, when our current political economy 
system is incomplete, and the law system unimproved socialism initial stage, some relatively rich social people and some people with some political power, when they basically have and effectively control corresponding social economy and political resources, they normally are out of their own economy or political benefit, to seek for political power protection or economic strength support.

Second, the main reason of lacking of rationality in Chinese civil political participation process are generally in two aspects: one is profound influence on traditional political culture. "people's thought", "offcier's standard consciousness" still cannot be understood. "Official" is the feature of feudal bureaucratic political system, and it at least includes four connotations: public power operation and "official" profit and willingness are the most fundamental starting point and foothold, strictly upper and lower level of the system, and the superior has absolute power to lower level of the young, taking the official, size and rank as the ruler, or they refer to rank level to measure people's social position and social mental life value, based on this, it forms the social mentality of fearing the officials.

Second, most of our Chinese economic development level and civil educated degree are low, thus, it lacks of relevant conditions to launch modern civil education and cultivate modern citizens with political skills and ideal spirit. Due to political skill shortage and limited political knowledge, current Chinese people cannot generally adopt rational and legal means for profit request.

Third, for the reason of current rich and poor difference, on one hand, it is due to individual quality and skill difference. In our current practitioners, the low educated degree of peasants and farmers' quantity occupy the most, due to the professional knowledge and skill shortage, their created wealth ability cannot compare with the professional technology talents' social wealth. According to labor distribution principle, then the low labor quality workers obtaining the pay is much lower than the high-quality labor workers.

\section{THE BASIC PATH OF GOOd POLITICAL ORDER ESTABLISHMENT}

At present, the goal of Chinese political development exists many problems in realization process. With the political system reform and civil main body consciousness awakening, orderly political participation and more and more political participation are recognized by society. This paper mainly analyzes how to establish good political order in current situation from government establishment, improving social distribution system and citizen political education of the several aspects.

First, strengthening and consolidating government legal authority, which is the premise of establishing good political order. For the current status of "capital power" and "power capital", we must pay attention to governmental own construction. Specifically, strengthening the authority of government must strengthen power balance, making government power operation open and transparent, increasing the strength of corruption crime and power crime, encouraging social citizens to supervise the government behavior. Secondly, as the government staff, they must pay attention to their behavior, constantly improving their own political quality and service consciousness, sticking to something and they should always remember that their government service object is vast people, instead of the few people. Finally, it should strengthen the government authority and improve administrative efficiency. In operation process, in the premise of ensuring quality, we should seek for the most economic and rapid method to implement various administration affairs, to improve mass satisfaction to government work.

Second, modern civil education is the important measure of establishing a good political order. In political participation process, the non-order state originates from civil political ability shortage and rational spirit lack to a great extent. The core of civil education is to cultivate modern citizens. For China, the important goal of civil education is to cultivate citizens' political skills, shaping citizens' rational spirit in political participation process.

Third, improving existing distribution system and maintaining social justice and fairness are the guarantee of establishing a good political order. Due to the social contradiction caused by polarization between the rich and the poor, it is the challenge and test for existing political order, so establishing a good political order make us must solve the current rich and poor polarization problem, realizing social justice and fairness, to improve our income distribution system. At present, constant increasing income gap in China has become an indisputable fact. The author thinks that we should adjust from the following aspects. First, we should strengthen relevant laws and improve existing policies. Secondly, as the government of management and service, it should strengthen the rectification of "capital power" and "power capital", and we should make effective supervision for the combination of money and political power. Finally, in order to achieve the purpose of reducing the social gap between the rich and the poor, it needs labor workers' labor quality to be generally improved. Finally, we use American scholar Samuel Huntington's words to again emphasize the importance of a good political order. Huntington said, "For many modernized countries, the first problem is not freedom, but to establish a legal public order. People can of course have order without freedom, but it can not have freedom without order."

\section{REFERENCES}

[1] Wang Jianrong. Authoritarian governance and the rule of law authority---problems and solutions of Chinese political development. From "contemporary world socialism problem, 2008,4.

[2] Xue Yong. China should say "no" to polarization between the poor and the rich, from "Teachers Expo, 2010,1.

[3] [America]Robert A. Dahl Modern political analysis. Shanghai Translation Press, 1987, P152-153. P96, P142.

[4] Yang Zhixia. On traditional political cultural barriers on the development of inner-party democracy, from Journal of CPC Yinchuan Municipal Committee Party School, 2009,2,11th,1,P26.

[5] [America]Samuel P. Huntington. Political order in changing society. Shanghai Century Press Group, 2008, P6. 